\title{
Poverty Reduction and Human Development: Issues and Strategy
}

\author{
Muhammad Aslam Khan ${ }^{1}$
}

"Growth is vital to reducing all aspects of poverty... But growth unaccompanied by other measures may neither boost the income of the poor much, nor lead to much progress on the non-income aspects of poverty. On both counts, human development progress has a part to play."(Poverty and Human Development, World Bank, 1980, p. 63)

\begin{abstract}
The paper assesses trends in poverty and improvements in the material conditions of life of millions of people living in poverty and buman deprivation. It discusses the growth and poverty dimensions and associated structural problems. Determinants of poverty in Pakistan are discussed with a view to identify areas of intervention and public policies. Poverty reduction and human development programmes are discussed to show that pumping financial resources to address the issue of poverty is not a correct strategy for poverty reduction and buman resource development. The paper discusses the poverty reduction strategy to assess government commitment to poverty reduction and human resource development in a sustainable manner. It concludes that poverty reduction and human development in Pakistan is dependent on many factors particularly the strengthening of institutional capacity and availability of human and financial resources.
\end{abstract}

\section{Introduction}

Reducing poverty, in its income and human development manifestations, is the over-arching objective of development. Development has its core transformations in economic activity, living conditions and values (Lewin, 2000a). Food security, basic education, freedom from disease and adequate nutrition are basic human needs that should be met for improvements in the material conditions of life (Lewin, 2000b). Poverty has many faces. Its magnitude, however, varies with its definition. Widespread literature on the issue has provided various explanations of poverty. For

${ }^{1}$ Chief, Poverty Alleviation Section, Planning Commission, Government of Pakistan. The findings, interpretation and conclusions expressed in this paper are entirely of those of the author and should not be attributable in any manner to the Planning Commission. Comments/views on the paper to Email: aslamk60@hotmail.com 
example, poverty is viewed as deprivation in well-being (World Bank, 2000); lack of resources to obtain the minimum necessities of life (Kakwani, 2001); a person is poor if his/her welfare or utility level falls below a certain level (Barr, 1993; Goedhart, T., Halberstadt, V., and van Praag, 1977); capability deprivation (Sen, 1987); lack of real opportunity of access to food (Sen, 1998), access to adequate source of nutrition (Reutlinger and Selowsky, 1976; Sukhate, 1977; and Srinivasan, 1981). According to the voices of the poor, poverty is much more than a simple explanation (Narayan, 2000). It is vulnerability of a person or a group of people to adverse events outside their control (World Bank, 2001).

Pakistan has achieved remarkable economic progress in terms of both growth in gross domestic product (GDP) and structural changes in the composition of output. Real GDP has grown at an annual average rate of above 5.5 per cent since the 1960s. Performance in the key sectors during this period has generally been satisfactory (Figure 1). Manufacturing valueadded has grown at more than 7 per cent per annum. The service sector has achieved an annual average growth rate of 6.1 per cent, while the growth of agricultural value-added averaged 4.2 per cent per annum (Government of Pakistan, 2001). Per capita income has increased from less than US\$100 in 1956 to US\$470 in 1999 (World Bank, 2000).

Figure 1: Growth rates of GDP and key sectors

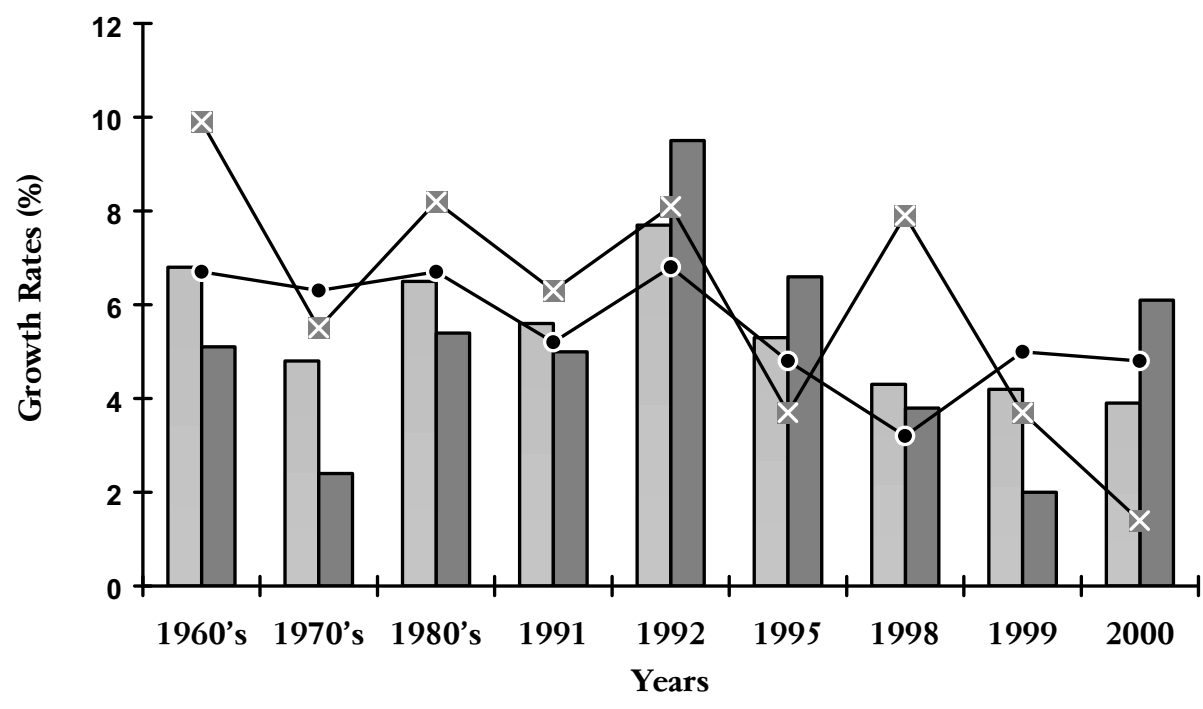

$\square$ GDP (fc) $\square$ Agriculture $-X-$ Manufacturing $-\bullet-$ Services 
Source: Government of Pakistan, 2001. Pakistan Economic Survey 200001, Ministry of Finance, Economic Adviser's Wing, Islamabad: Government of Pakistan.

Notwithstanding this generally good performance, the economy has not done as well as it could have. Growth has not been uniform. It failed to 'trickle down' to the poor and as a result social inequalities widened (Haque and Montie1, 1992). Evidence from various sources suggests that poverty in Pakistan since the early 1990s is rising. The prime reason of increase in poverty in the 1990 s is attributable to the relatively low rate of economic growth (implying a slow increase in per capita income) coupled with rising unemployment and level of cost of living (Planning Commission, 2001); pressure of population growth on goods and services and social deprivation, which include access to physical and social assets such as certain quantity of food, land, health care, education, drinking water, and sanitary facilities. Low investment in human resource development also intensifies the poverty problem (ADB, 1997).

After 52 years into the life of Pakistan, the country is still faced with the problem of weak social indicators. Even now almost every indicator of well-being such as literacy, education, health, nutrition, safe drinking water and sanitation, access to family planning services compares poorly with countries at the same level of per capita income (Appendix-I). Pakistan has a low level of adult literacy with some 52 per cent of the population over 10 years being literate. Illiteracy is particularly high for the poor and especially women and girls. This comprises 20.6 million males and 29.4 million females (HDC, 1999). The country, in terms of the human development index (HDI) is ranked 138 out of 174 countries (UNDP, 1999). Pakistan also fares worse on all the six dimensions of governance (less government effectiveness, more graft, political instability, more regulatory burden, less rule of law and less accountability) measured by Kaufmann et a1. 1999 b.

A number of studies have measured and defined poverty in Pakistan. Most of these studies measured poverty in absolute terms based on income or consumption as the assessment basis. The calorie-based approach used widely to determine poverty, however, differ significantly for methodologies and assumptions used (Appendix-II). These studies suggest that poverty in Pakistan increased rapidly in the 1960s, then declined sharply in the 1970s up to mid-1980s and began to increase again from the late 1980s (Naeem, 1973, Irfan and Amjad, 1984; Amjad and Kemal, 1997; Jafri, 2000, Qureshi and Arif, 2000). Using the same approach and consistent time series data and 2150-calorie average per adult equivalence calories requirements, it has 
been observed that between 1986-87 and 1999-2000 poverty has increased rapidly from 21.3 per cent in 1996-97 to 30.0 per cent in 2000-01 (Figure 2 ). The incidence of poverty is higher in rural areas compared to urban areas.

Figure 2: $\quad$ Poverty incidence - headcount (\%)

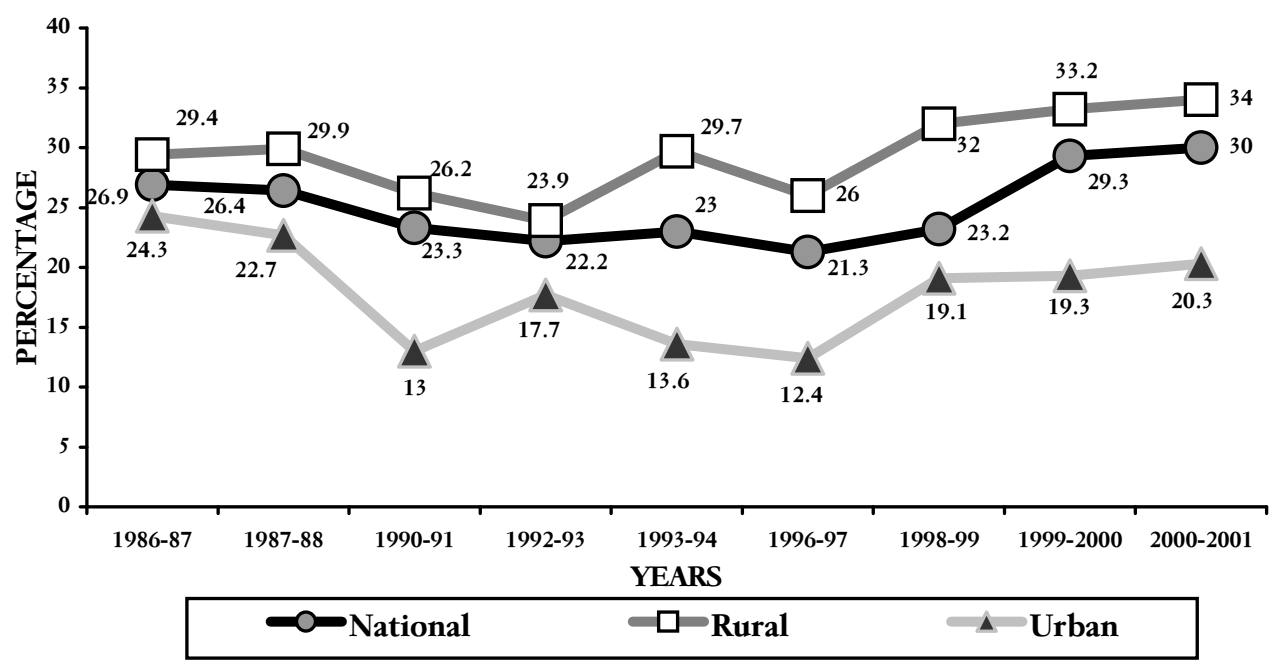

Source: Appendix III.

\section{Determinants of Poverty}

a) Economic growth: The country has experienced a continuous decline in the overall growth rate of GDP of about 6 per cent before the 1990 s to 2.6 per cent in 2000-01. This means that the growth in per capita income has been declining sharply reaching around 0.5 per cent in 2000-01.

b) Population pressure: The pressure of high population growth translates into millions without formal employment and large numbers of new entrants into the job market each year. A large population has created numerous difficulties in the fight against poverty, in realising the objectives of improved human welfare, in enhancing the severely depressed levels of national savings and in protecting the already vulnerable environment.

c) Rising rate of unemployment: An associated fundamental issue is the phenomenon of unemployment in the country. The situation in 
this respect is simply grim. Overall unemployment is over 10 per cent. Almost 40 per cent of the new entrants to the labour force every year, or about 500,000 persons are being added to the pool of the unemployed every year. The unemployment rate is higher in educated (above matriculation) youth.

d) Low level of national savings: The country has not been generating adequate national savings to finance growing investment levels. National savings lingering around 12-13 per cent of GDP are low for the financing of required investment levels.

e) Fiscal imbalances: The country has also to grapple with fundamental fiscal imbalances, ranging from 5 per cent of GDP on the low side to 8-9 per cent on the high side, over the last many years. The public sector has been a dis-saver over a long period of time. Analysis of government's finances indicate that in the past two decades government revenue remained around 17 per cent of the GDP and tax to GDP ratio languished around 13-14 per cent. Government expenditure, in the same period initially increased from 22.9 per cent in $1980-81$ to 26.7 per cent in 1991-92 and subsequently has been reduced to 23.4 per cent in 1999-2000. All the increase in government expenditure has been in nondevelopment expenditure for increased debt servicing liability payments. The burden of fiscal adjustment, therefore, fell heavily on public sector development expenditure, which as a proportion of GDP reduced from around 8 per cent in $1987-88$ to less than 3.0 per cent in 1999-2000. The sharp decline in public sector development expenditure has severely influenced the creation of physical and social infrastructure and its maintenance. Since 1987-88 at no point of time was the government able to meet the fiscal deficit targets agreed with the international development institutions. The fiscal deficit stayed put at around 5-9 per cent in the past 20 years. Figure 3 indicates the trend in government finances. 
Figure 3: Trends in government finances

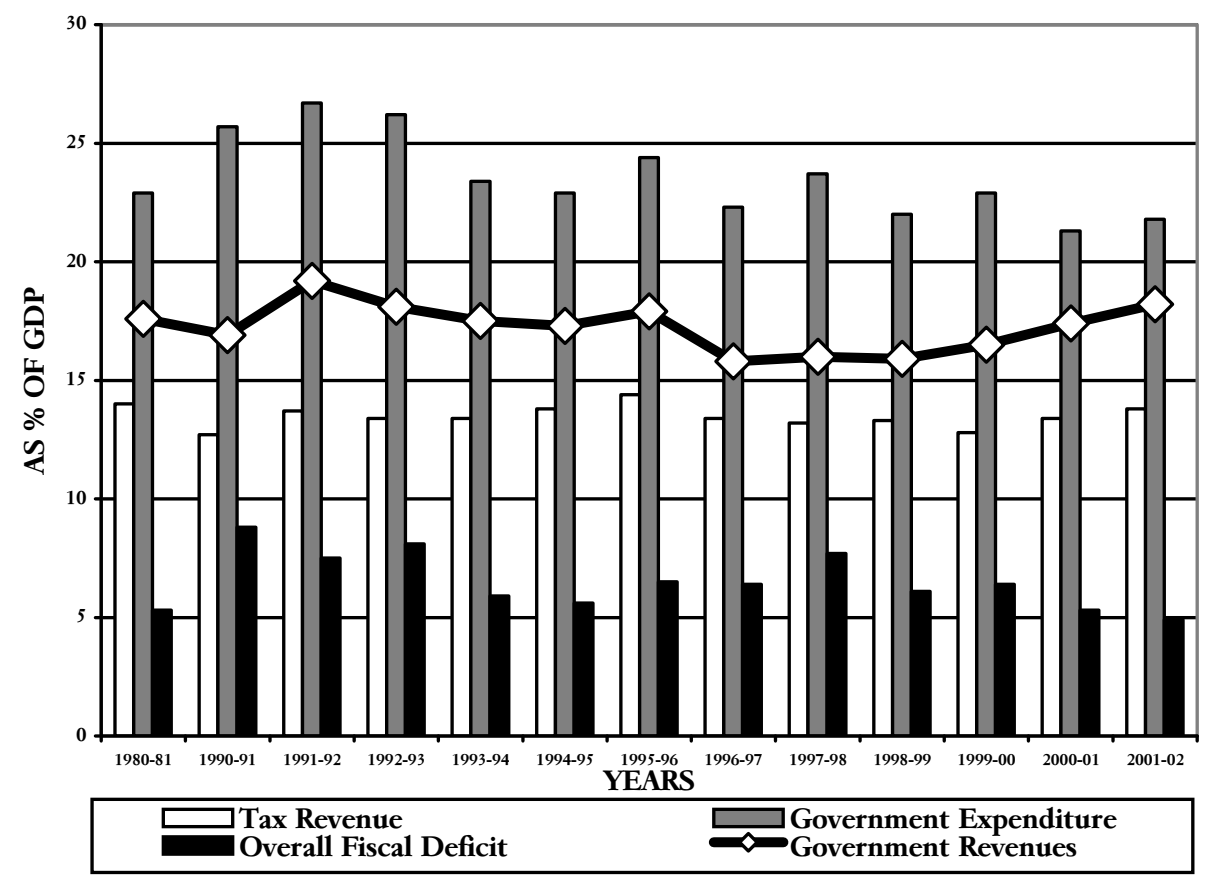

Source: Appendix-IV.

f) Debt burden: Large public sector deficits and low national savings have resulted in the rapid growth of domestic and foreign debt, which has now swelled to about 97 per cent of GDP and 600 per cent of the country's annual revenues-one of the highest in the world. The debt hangover has become one of the most formidable problems in recent years, and has acted as a major constraint on economic growth, social development, and poverty reduction.

g) Pro-poor public expenditure: The extent to which a country's public expenditure is directed towards the goal of poverty alleviation is of central importance. Public expenditure has the potential to reduce poverty in at least three major ways: i) primary education, basic health care, safe water and sanitation; ii) the basic infrastructure needed by poor farmers, micro entrepreneurs, and labour-intensive manufacturers to provide livelihoods, and iii) cash and food transfers to reduce the vulnerability of the marginalised segments of society.

Nevertheless, continuously declining share of development expenditure in total government expenditure from about 41 per cent in 1980-81 
to about 13 per cent in 2000-01 (Figure-4) has badly influenced the provision of public goods and services and maintenance of social and community services - education, health, safe water and sanitation and civic participation of the bulk of the population of the country. The public expenditure (development and recurring) on the provision of social services which increased from 5.9 per cent of the GDP in 197778 to 6.7 per cent in 1992-93, due to fiscal consolidation under the structural adjustment programme declined to 5.1 per cent of the GDP in 2000-01. Development expenditure on basic infrastructure of transport (roads, bridges and farm to market roads), communication (telecommunication and postal services) and rural electricity declined sharply from 1.2 per cent of the GDP in 1977-78 to less than one per cent by $2000-01$.

Figure 4:Trend in government expenditure (\% share)

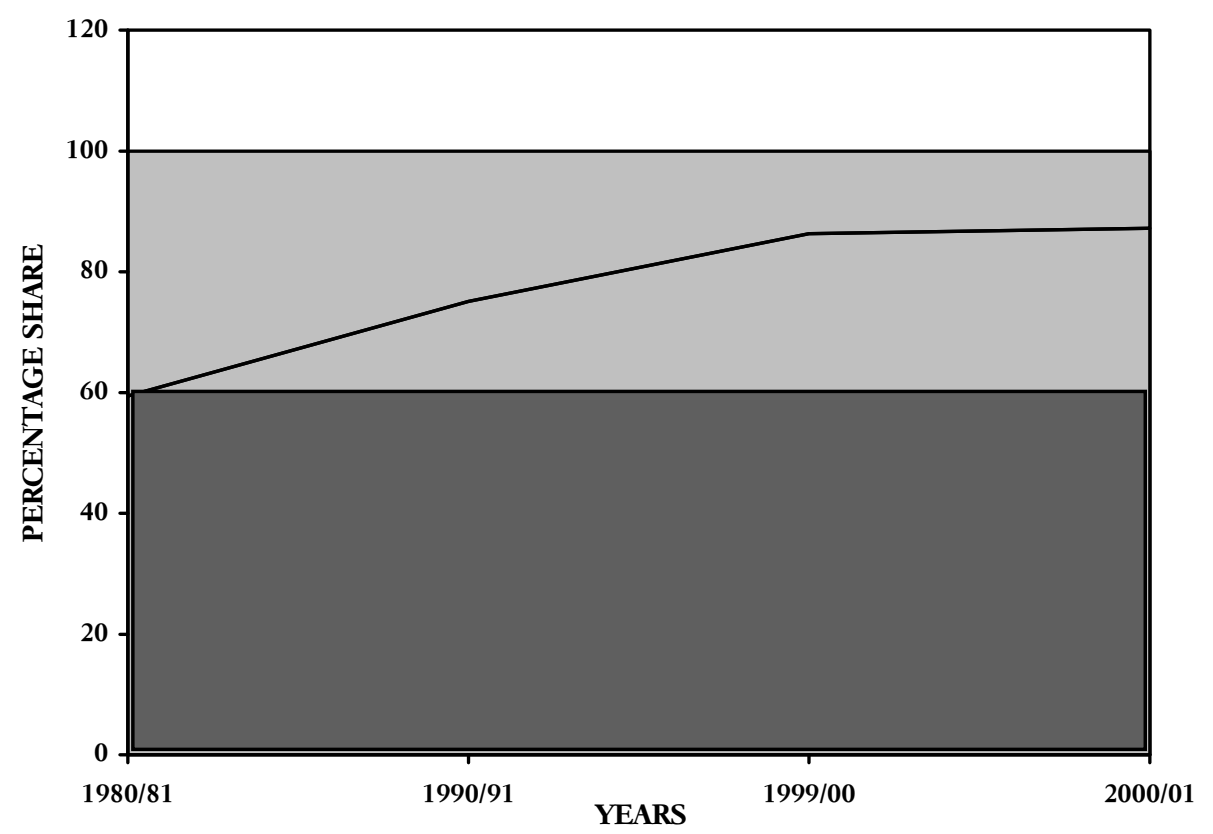

Current Expenditure $\quad \square$ Development Expenditure

Source: Appendix-V

h) Trade and balance of payments policies: A general failure of the trade and balance of payments policies has resulted in high trade and current account deficits, giving rise to repeated balance of payments 
crises in recent years. Pakistan exports have been rising very slowly, workers remittances have shrunk to less than $\$$ one billion, the debt repayments burden is increasing and import is somewhat uncompressible. These have impacted on the growth and economic prospects of the country as well as on its capacity to substantially reduce poverty, especially in the short run.

i) Agriculture sector's growth potential not fully exploited: The real sectors such as agriculture were neglected. In fact ineffective, misdirected and misplaced agricultural policies, including water use, resulted in enormous imports of wheat, edible oil, tea and other food items. While urban poverty is quite high, poverty in rural areas is worsening even more and cannot be seriously tackled without a renewed and re-invigorated agricultural sector. Also, the prices of food items have a direct impact on the poverty conditions in Pakistan.

j) Manufacturing sector policies: The past policies of developing the capital-intensive industrial sector under heavy protection gave rise to a manufacturing sector, which is saddled with many negative valueadding activities. It is not diversified and is generally not able to compete either at home, without heavy protection, or in the competitive international market place. New investment in the sector is minimal, skill developments are negligible and induction of modern technology rather infrequent and weak. The development of Small and Medium Enterprises was not encouraged and as a result small industries that employ about 70 per cent of the labour force never got the attention and support they deserved. Consequently both the large and small-scale segments of the industrial sector remain vulnerable especially under the new, globalising environment.

k) Lack of technical know-how: Skill and knowledge levels which require integrating in modern sectors is often beyond the reach of the poor. This makes it difficult for them to participate in economic growth and globalisation.

1) Indigent infrastructure: The economic infrastructure related to the transportation network of roads, railways, ports, irrigation, energy etc. is either missing or weak.

m) Poor human resource development (HRD): HRD has also suffered enormously because the quality of the educational system from the primary to the highest level, the sufficient availability of skills development and training arrangements; the health sector's 
efficiency and effectiveness, the adequacy of safe water supply and even a minimum level of sanitary facilities have been badly lacking for want of (a) priority attention and (b) allocation of finances.

\section{Impact of Poverty Reduction Programmes}

The government, since the mid-eighties has shown a strong commitment to poverty reduction and human resource development. Additional investment of Rs. 450 billion has been made by the government for specialised programmes for poverty reduction and physical and social infrastructure development (Table 1). The emphasis of these programmes was on the creation of physical infrastructure (farm to market roads, village electrification, etc.) and delivery of basic social services - primary education, primary health care, safe drinking water and sanitation, rural development, rural electrification and family welfare services.

Table-1: Special programmes for poverty reduction (Billion Rupees)

\begin{tabular}{lcc}
\hline \multicolumn{1}{c}{ Programmes } & Period & Expenditure \\
\hline Prime Minister's Five Point & $1985-88$ & 3.3 \\
Programme & & \\
People's Programme & $1988-91$ and $1994-97$ & 16.2 \\
Tameer-e-Watan Programme & $1991-93$ and 1998-2000 & 9.7 \\
Social Action Programme & $1993-2002$ & 419.6 \\
Total: & $1985-2002$ & 448.8 \\
\hline
\end{tabular}

Source: Planning Commission, Public Sector Development Programme (various issues)

Realising that long-term economic growth and poverty alleviation could not be achieved without raising the level of human development, the Social Action Programme (Phase-I) was launched by the government in 199394 for three years with an investment of Rs. 127 billion. SAP addressed four important sectors, namely primary education, basic health care, family planning and rural water supply and sanitation. It strived specifically to reach out to rural women, children and people at large at the grass root levels. At the conclusion of Phase- I of SAP the government has launched Phase-II of SAP for a period over 5 years from January 1, 1997 to June 30, 2002 at a cost of about Rs. 500 billion. The scope of SAP-II was expanded to cover middle schools and non-formal education in the education sector, Tehsil level referral 
hospitals, tuberculosis and nutrition in the health sector and water supply and sanitation in urban slums. The government commitment to the programme was highest. Despite a severe resource problem, SAP expenditures were protected as core expenditure. As shown in Table-1 by end June 2001 about Rs. 420 billion have been spent on the programme.

In the absence of proper evaluation and impact analysis of these programmes, it is difficult to assess the impact on improvements in the material condition of life, a sustainable livelihood and equitable access to public services for the poor. It, however, transpires from the available data from various sources that in the past 15 years very little improvement has been witnessed in social indicators. Particularly, SAP failed to achieve desired improvements in social indicators. The Pakistan Integrated Household Survey (PIHS) data indicate that in recent years despite special attention to the development of social indicators primary school gross enrolment and net enrolment has dropped from 73 per cent and 46 per cent in 19901-91 to 71 per cent and 42 per cent in 1998-99 respectively. Similarly, indicators on sources of drinking water and sanitation have shown declining trends. The population welfare and health indicators have shown slight improvement over the same period (Appendix-VI).

\section{Pre-Conditions for Poverty Reduction and Human Development}

It has been recognised that without sustainable growth, the country would be embarking upon a road that leads to the redistribution of poverty. The poverty reduction strategy, therefore, aims to broaden and deepen the development process in ways that enlarge the basis of achieving a high rate of economic growth with a combination of mutually reinforcing factors. These include a high rate of economic growth, which have translated directly or indirectly into increase in disposable incomes and strong commitment to investments for human resource development, particularly education and health.

Research shows that the rate of growth of an economy depends on the increase in the quantity and quality of the capital stock and on the quality of the labour force. Education increases the quality of the labour force. The rate of return for education is higher than for any other kind of investment (Action Aid Pakistan, 1999). It is considered as a social instrument for developing human resources and forming human capital and increasing national productivity (UNESCO, 1997). Development of human capital, especially education, is one of the keys to reduce poverty (World Bank, 1990). No country has experienced a substantial degree of economic 
development without first achieving a level of basic literacy in a substantial proportion of the population (Barr, 1993).

Many countries, which have combined pro-growth development policies with investments in health and education, have witnessed rapid economic growth, improvement in living standards and speedy reduction of poverty. For example, Japan, the East Asian Industrialising Countries (the Republic of Korea, former Hong Kong, Singapore, Taiwan, Malaysia, and Thailand); and China have achieved rapid socio-economic progress through heavy investment in basic education and technical skills (HDC, 1998; Annan, 2000). Research also supports the fact that investment in girls' education translate directly and quickly into better nutrition for the whole family, better health care, declining fertility, poverty reduction and better overall economic performance. An equitable access to education is a powerful tool to reduce poverty (Hossain, 1993).

The poverty reduction strategy recognises that in the absence of a healthy and literate population it would be difficult for Pakistan to bring about a real increase in productivity and desired changes in society. The strategy recommends priority actions to create an enabling environment for human resource development. Education and health are the key target sectors through which human development of the poor can be achieved. In practical terms for education, this means more well trained teachers, reformed curricula in schools, colleges and universities, emphasis on science, engineering and information technology. For health, it means more doctors, nurses, paramedical staff and more primary and secondary health care centers distributed all over the country to ensure affordable access to the poor.

\section{Strategy for Poverty Reduction and Human Resource Development}

Pakistan's poverty reduction strategy subscribes strongly to the belief that economic development to be really meaningful and sustained must take into account the economic, social, and governance dimensions (Planning Commission, 2001a). It emphasises that the benefit of development must accrue proportionately to all citizens, including the poor, unemployed, marginalised groups and disadvantaged. It should ensure equitable distribution of wealth from expanding and new sources of wealth, while promoting human resource development. Economic development should create a productive and disciplined labour force and develop necessary skills to meet the challenges in agricultural and industrial development. It recommends the empowerment of communities through greater involvement of the poor in the formulation of policies for economic and social development and in the management of their affairs. The focus of the poverty reduction strategy is on: 
- Directing public policy debate on the needs of the poor.

- Bringing about an effective transformation of society, by forging partnerships and alliances with civil society and the private sector.

- Understanding the nature of poverty, and using that as a guide for all public actions.

- Empowering the people, especially the most deprived, by increasing access to factors of production, particularly land and credit.

The strategy is based on five major elements.

I. Economic Reforms: Promotion of economic growth and creation of employment opportunities.

II. Physical Asset Creation: Education will create human capital. In addition, programmes of land allocation, credit, Zakat and $U s h r$ for capital formulation will also be used to create physical assets for the poor. Both human and physical capital will enhance the incomeearning capacities of the poor.

III. Social Asset Creation: Creation of social assets by ensuring costeffective provisions (public or private) of basic needs of the poor i.e. access to education, health; nutrition; water supply and sanitation. This is for human and social capital formation for the poor through a participative process involving the poor and civil society.

IV. Social Safety Net: For the chronic or transitionally vulnerable groups this will provide adequate supplementary transfers to ensure the satisfaction of basic needs i.e. food, shelter, etc.

V. Governance: Improved efficiency in the Public and Corporate sectors to provide Rule of Law and, inter alia, improve the efficiency of service delivery.

The main elements of poverty reduction relating to human resource development and improvements in civic service are discussed briefly below:

\section{a. Education}

The education sector strategy and goals, targets and policy matrix (Table-2) have been finalised after exhaustive consultations with key stakeholders. A holistic approach for the planning of human resource 
development has been adopted. The strategy is based on Education Sector Reforms (ERS) Action Plan. The ESR is based on a long-term framework 2001-2011 with a three-year action programme 2001-2004. The main features of the reform agenda include macro level reforms in planning, procedures, resource mobilisation and utilisation; sector wide approaches for reinforcement of linkages between sub-sectors (i.e. primary/elementary/ non-formal literacy, secondary/technical, higher education and quality assurance structures); strategies and milestones for implementation; integration with the Social Action Programme (SAP); Education For All (EFA); institutional reforms at all tiers of government; delivery of quality education; and a technical and vocational education bias at the secondary education levels.

To meet the human resource needs of the country a shift to Science and Technology is being made at the Secondary and Higher Education levels (Planning Commission, 2001) thereby creating employment options for educated youth.

An innovative element of ESRs is the emphasis on the inculcation of employable skills alongside education. This will be achieved through the introduction of a technical education stream at the secondary school level. This plan aims at introducing a skill development group in the ninth and tenth grade, parallel to the existing science and arts group, in 1200 existing secondary schools with adequate workshop space and in 60 model technical high schools that will be established under this programme. Training will be imparted in trades that are selected with the consultation of local industry, thereby creating employment linkages with industry. The programme will be supplemented through the provision of micro-credit to encourage selfemployment.

\section{b. Health}

The health sector strategy places greater focus on a continuous shift from curative services to the promotive and preventive health services through improving the primary health care system, especially in the area of communicable and infectious diseases, reproductive health, child health, and nutrient deficiencies. The strategy is based on "Health Care for All" which is accessible, acceptable and affordable. The implementation of the strategy is expected to reduce the prevailing burden of diseases, especially preventable disease. The emphasis will be on improving the service delivery mechanism, which will be efficient, equable and effective. During the course of the implementation of the strategy preventive and promotive aspects will get top priority (Planning Commission, 2001b). 


\section{c. Population Programmes}

The population welfare strategy proposes the implementation of a Comprehensive Reproductive Health Package with an improved coordination of reproductive health programmes. A National Reproductive Health Policy has been formulated to improve the reproductive health status of women. The service delivery infrastructure of the population programme operates through 1,658 Family Welfare Centers, 131 Mobile Service Units, and 106 Reproductive Health Centers and 12,000 Village Based Family Planning Workers (VBFPWs) providing reproductive health and family planning services to both the urban and rural population in the country. The FWCs are proposed to be upgraded as MCH Centers after the provision of necessary inputs of training and equipment. These Centers will deliver a whole range of PHC services (including reproductive health) with a clear focus on contraceptive services. The 12,000 VBFPWs of Ministry of Population Welfare (MoPW) and 43,000 Lady Health Workers (LHWs) of the Ministry of Health have been unified as one cadre of 55,000 Family Health Workers (FHWs) and will be brought together technically at par with each other for the provision of $\mathrm{PHC} / \mathrm{RH}$ service at the grassroots level. These workers will be trained further in a phased manner to provide midwifery services at the community level. The entire Programme will be backed by an independent media and advocacy campaign, for high social marketing and NGOs involvement.

Restructuring of the PHC programme at the federal, provincial, and the district levels will transform the system into a people-centered and output-oriented initiative. Also, good governance reforms underway in the population and health sectors are based in the ICPD holistic approach that prescribes integration of family planning and reproductive health with the primary health care framework. These will be decentralised at the provinces, which will involve transfer of fiscal and administrative control over finances, planning, and decision-making, to local levels. Similarly, transfer of power to districts under the new devolution structure would improve efficiency at the grassroots outreach services.

\section{d. Water Supply and Sanitation}

At present 63 per cent of the country's population has access to safe drinking water ( 83 per cent in urban areas while 53 per cent in rural areas), whereas planned sanitation facilities are available to about 39 per cent of the total population $(59$ per cent in urban areas while 27 per cent in rural areas). Water supply facilities will be increased from 63 per cent (in 200001 ) to 66 per cent in 2003-2004- 86 per cent in urban areas and 56 per cent in rural areas. The planned sanitation facilities will be increased from 39 per cent in 2000-01 to 43 per cent in 2003-04. 


\section{Poverty Reduction and Human Development - Targets}

The poverty reduction strategy will result in not only containing poverty; it will bring definite changes required to systematically empower the poor to move towards self-sustenance. Table 2 below give details of medium to long-term goals, targets and instrument matrix for poverty reduction and human resource development.

Table 2: Poverty Reduction \& Human Development - Goals, Targets and Instrument Matrix

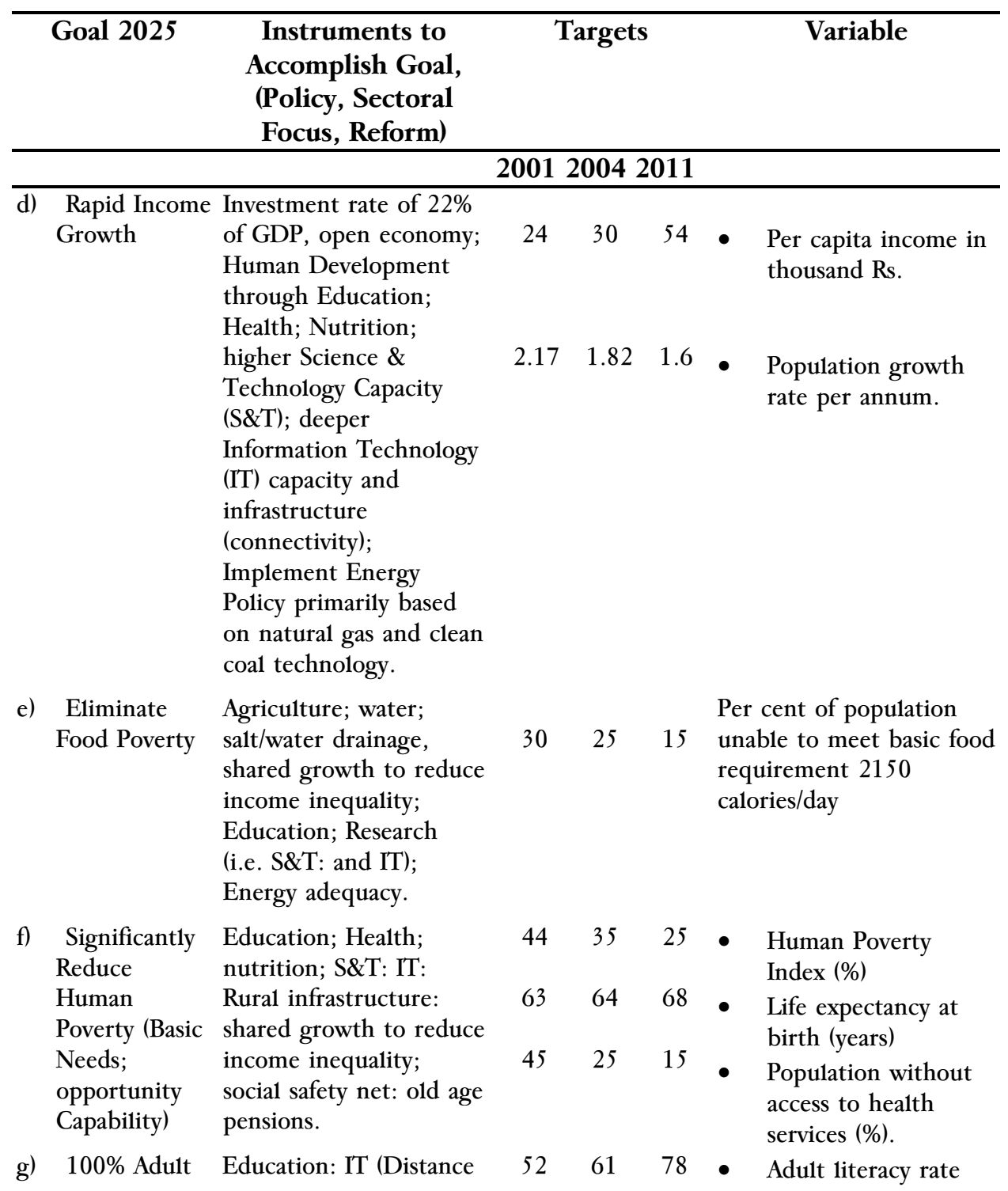


16 The Lahore Journal of Economics, Vol.6, No. 2

\begin{tabular}{|c|c|c|c|c|c|c|}
\hline & Literacy & Education): Expansion & 39 & 47 & 67 & Female literacy rate \\
\hline & Universal Pre- & of teachers, schools, and & 83 & 94 & 104 & - Primary \\
\hline & College & teacher training. & 55 & 64 & 80 & \\
\hline & Education & & 38 & 49 & 70 & - Secondary \\
\hline \multirow[t]{5}{*}{ h) } & \multirow{5}{*}{$\begin{array}{l}\text { Eliminating } \\
\text { Malnourish- } \\
\text { ment for } \\
\text { under } 5 \\
\text { Children }\end{array}$} & \multirow{5}{*}{$\begin{array}{l}\text { Targeted food } \\
\text { distribution programme } \\
\text { with deep involvement } \\
\text { of communities: NGOs } \\
\text { Using teacher - parent } \\
\text { links to expand } \\
\text { awareness. }\end{array}$} & 39 & 35 & 20 & - Malnutrition of \\
\hline & & & 111 & 77 & 46 & $\begin{array}{l}\text { Child Mortality Rate } \\
\text { (per } 1000 \text { live births) }\end{array}$ \\
\hline & & & 400 & 300 & 250 & Maternal Mortality \\
\hline & & & & & & $\begin{array}{l}\text { Rate (per 100,000 live } \\
\text { births). }\end{array}$ \\
\hline & & & 25 & 12 & 7 & $\begin{array}{l}\text { - Incidence of Low } \\
\text { Birth weight babies } \\
\text { (\%). }\end{array}$ \\
\hline i) & $\begin{array}{l}\text { Clean water } \\
\text { for all Citizens }\end{array}$ & $\begin{array}{l}\text { Investments in Water } \\
\text { Supply System: strict } \\
\text { enforcement of emission } \\
\text { control laws: Enhancing } \\
\text { institutional capacity to } \\
\text { monitor compliance and } \\
\text { enforce. }\end{array}$ & 63 & 68 & 84 & $\begin{array}{l}\text { Population with } \\
\text { Access to Safe Water } \\
\text { (\%). }\end{array}$ \\
\hline j) & $\begin{array}{l}\text { Clean Air for } \\
\text { all Citizens }\end{array}$ & $\begin{array}{l}\text { Ten Year Crash } \\
\text { Programme of } \\
\text { Legislation and } \\
\text { enforcement to control } \\
\text { emissions of } \mathrm{SO}_{2,} \mathrm{No}_{x} \text {, } \\
\mathrm{PM}_{10} \text { in hot spots. } \\
\text { Natural gas and clean } \\
\text { coal energy policy. }\end{array}$ & 50 & 40 & 20 & $\begin{array}{l}\text { Population without } \\
\text { Access to clean air } \\
\text { (\%) }\end{array}$ \\
\hline k) & Rule of Law & $\begin{array}{l}\text { Civil service Reform, } \\
\text { Judicial Reform: Police } \\
\text { Reform: Implementing } \\
\text { Local Government } \\
\text { devolution: Education. }\end{array}$ & $20 \%$ & $75 \%$ & $100 \%$ & $\begin{array}{l}\text { - Significantly } \\
\text { mainstream the } \\
\text { Reforms i.e. } \\
\text { implement current } \\
\text { programme. }\end{array}$ \\
\hline \multirow[t]{2}{*}{ 1) } & \multirow[t]{2}{*}{$\begin{array}{l}\text { Enhance } \\
\text { Pakistan's } \\
\text { Scientific } \\
\text { Capability }\end{array}$} & $\begin{array}{l}\text { Crash Programme to } \\
\text { develop S\&T }\end{array}$ & 116 & 295 & 1200 & $\begin{array}{l}\text { Number of scientists } \\
\text { and engineers per } \\
\text { million population }\end{array}$ \\
\hline & & $\begin{array}{l}\text { Concurrently, increased } \\
\text { allocation to } R \& D\end{array}$ & 0.2 & 0.5 & 1.2 & $\begin{array}{l}\text { allocated to Research } \\
\text { \& Development. }\end{array}$ \\
\hline m) & $\begin{array}{l}\text { Human } \\
\text { Development } \\
\text { Index }\end{array}$ & $\begin{array}{l}\text { All of the above } \\
\text { implemented effectively } \\
\text { and as a package. }\end{array}$ & 135 & 120 & 90 & $\begin{array}{l}\text { - Rank on Human } \\
\text { Development in the } \\
\text { United Nations }\end{array}$ \\
\hline
\end{tabular}

Source: Planning Commission, 2001b. 


\section{Resources for Poverty Reduction Strategy}

Availability of adequate resources is necessary to achieve the target set for poverty reduction and human development. The poverty reduction strategy envisages a reasonable increase in financial resources so that the main targets of the plan are accomplished. The resources required to implement the proposed poverty reduction strategy are given in Table 3 with details:

Table 3: Public and Private Sector Expenditure for Poverty Reduction (2001-2011)

\begin{tabular}{rccc}
\hline $2000-01$ & $2003-04$ & $2010-11$ \\
\hline (Bill. Rs) \% GDP & (Bill. Rs) \% GDP (Bill. Rs) \% GDP
\end{tabular}

I. PUBLIC SECTOR

A. Budgetary Expenditure

$\begin{array}{lrrrrrr}\text { a) Development Expenditure } & 37.5 & 1.1 & 62.3 & 1.4 & 128.1 & 1.5 \\ \text { b) Current Expenditure } & 79.5 & 2.3 & 136.4 & 2.5 & 267.4 & 3.0 \\ \text { - Social Services } & 75.0 & 2.2 & 129.9 & 2.3 & 247.1 & 2.7 \\ \text { - Community Services } & 3.4 & 0.1 & 4.7 & 0.1 & 18.3 & 0.2 \\ \text { - Others } & 1.0 & 0.0 & 1.8 & 0.1 & 2.0 & 0.1 \\ \text { Total A: } & 117.0 & 3.4 & 198.7 & 3.9 & 395.5 & 4.5\end{array}$

B. Targeted Transfers

\begin{tabular}{|c|c|c|c|c|c|c|}
\hline a) Zakat & 6.8 & 0.2 & 14.4 & 0.3 & 45.8 & 0.4 \\
\hline b) Food Support Programme & 2.3 & 0.1 & 2.3 & 0.0 & 0.0 & 0.0 \\
\hline c) Social Security (EOBI) & 1.5 & 0.0 & 2.2 & 0.0 & 9.2 & 0.1 \\
\hline $\begin{array}{l}\text { d) Health Insurance, and } \\
\text { Workers Welfare Fund }\end{array}$ & 2.5 & 0.1 & 4.0 & 0.1 & 18.3 & 0.2 \\
\hline e) Housing Finance & 0.3 & 0.0 & 0.6 & 0.0 & 9.2 & 0.1 \\
\hline Total B: & 13.4 & 0.4 & 23.5 & 0.4 & 82.5 & 0.8 \\
\hline Total Public Sector (A+B) & 130.4 & 3.8 & 222.2 & 4.3 & 478.0 & 5.3 \\
\hline \multicolumn{7}{|l|}{$\begin{array}{l}\text { II. PRIVATE SECTOR } \\
\text { (Indicative) }\end{array}$} \\
\hline I. Zakat & 13.6 & 0.4 & 18.6 & 0.5 & 54.9 & 0.6 \\
\hline $\begin{array}{ll}\text { II } & \text { Non-Zakat Money } \\
\text { (Gifts, Assistance etc) }\end{array}$ & 17.1 & 0.5 & 23.9 & 0.5 & 54.9 & 0.6 \\
\hline a) Volunteering & 30.7 & 0.9 & 41.1 & 0.9 & 109.8 & 1.2 \\
\hline
\end{tabular}


The Labore Journal of Economics, Vol.6, No.2

\begin{tabular}{|c|c|c|c|c|c|c|}
\hline $\begin{array}{l}\text { b) Workers Remittances } \\
\text { from abroad }\end{array}$ & 30.7 & 0.9 & 41.1 & 0.9 & 109.8 & 1.2 \\
\hline Total II: & 92.1 & 2.7 & 124.7 & 2.8 & 329.4 & 3.6 \\
\hline TOTAL I+II & 225.5 & 6.5 & 346.9 & 7.1 & 807.43 & 8.9 \\
\hline
\end{tabular}

Bill=Billion

Source: Planning Commission, 2001b.

\section{Conclusions}

At present, the magnitude and complexity of the problem of poverty is staggering. Sound macroeconomic policies, growth enhancing structural reforms, and good social policies are the conditions for sustainable growth that generate higher levels of employment and real income. Growth with unequal benefits inhibit widespread social improvement and is, therefore, not satisfactory. The empirical evidence suggests that economic growth reduces poverty and increased expenditure in human development. Pakistan, with a high rate of economic growth above 5 per cent in the past 30 years and increased expenditure on social sector development failed to achieve the desired improvements in the life of the poor.

The approach of the poverty reduction strategy to address all the issues causing poverty and human deprivation holistically is a welcome development, but this is not enough. To reduce poverty and human deprivation substantial collective efforts are needed.

The success of poverty reduction efforts is dependent on the development of human capacities through education and training and the empowerment of communities. The communities should be encouraged to come forward with their demands. This will make a significant contribution to poverty reduction and efficient use of resources. This will create a sense of ownership among the poor over goods and services provided by the public sector. 
Muhammad Aslam Khan 19

\section{Appendix-I}

\section{Comparison of selected social indicators (Countries in the region)}

\begin{tabular}{|c|c|c|c|c|c|c|c|}
\hline INDICATORS & & & & & & & \\
\hline & PAKISTAN & CHINA & MALAYSIA & $\begin{array}{c}\text { BANGLA } \\
\text { DESH } \\
\end{array}$ & $\begin{array}{c}\text { SRI- } \\
\text { LANKA }\end{array}$ & INDIA & NEPAL \\
\hline $\begin{array}{l}\text { Human } \\
\text { Development } \\
\text { Index (HDI) }^{1}\end{array}$ & 138 & 98 & 56 & 150 & 90 & 132 & 144 \\
\hline $\begin{array}{l}\text { Gender-related } \\
\text { Development } \\
\text { Index }(\mathrm{GDI})^{1}\end{array}$ & 111 & 79 & 52 & 123 & 76 & 112 & 121 \\
\hline $\begin{array}{l}\text { Gender } \\
\text { Empowerment } \\
\text { measure }^{1}\end{array}$ & 101 & 40 & 52 & 83 & 80 & 95 & .. \\
\hline $\begin{array}{l}\text { Human Poverty } \\
\text { Index })^{1}\end{array}$ & 71 & 30 & 18 & 73 & 33 & 59 & 85 \\
\hline $\begin{array}{l}\text { GNP per Capita } \\
\text { (US\$) } 1997\end{array}$ & 500 & 860 & 4530 & 360 & 800 & 370 & 220 \\
\hline $\begin{array}{l}\text { Real GDP per } \\
\text { capita }(P P P)^{2}(1997 \\
\text { US\$) }\end{array}$ & 1560 & 3130 & 8140 & 1050 & 2490 & 1670 & 1090 \\
\hline Female & 701 & 2485 & 5115 & 767 & 1452 & 902 & 763 \\
\hline Male & 2363 & 3738 & 11081 & 1320 & 3545 & 2389 & 1409 \\
\hline $\begin{array}{l}\text { Population below } \\
\text { income poverty } \\
\text { line (\% living } \$ 1 \text { a } \\
\text { day- } 1989-94)\end{array}$ & 11.6 & 29.4 & 7.4 & 28.5 & 4.0 & 52.5 & 53.1 \\
\hline $\begin{array}{l}\text { Life expectancy at } \\
\text { birth (years) (1997) }\end{array}$ & & & & & & & \\
\hline Female & 63.7 & 72.0 & 74.3 & 58.2 & 75.4 & 62.9 & 57.1 \\
\hline Male & 63.8 & 67.9 & 69.9 & 58.1 & 70.9 & 62.3 & 57.6 \\
\hline $\begin{array}{l}\text { Infant Mortality } \\
\text { rate (per } 1000 \text { live } \\
\text { births) }\end{array}$ & 90 & 38 & 10 & 81 & 17 & 71 & 75 \\
\hline $\begin{array}{l}\text { Adult Literacy (\%) } \\
\text { (1997) }\end{array}$ & 45.0 & 82.9 & 85.7 & 38.9 & 90.7 & 53.5 & 38.1 \\
\hline
\end{tabular}


20 The Lahore Journal of Economics, Vol.6, No.2

$\begin{array}{llllllll}\text { Female } & 32.6 & 74.5 & 81.0 & 27.4 & 87.6 & 39.4 & 20.7 \\ \text { Male } & 56.5 & 90.8 & 90.2 & 49.9 & 94.0 & 66.7 & 55.7\end{array}$

Public expenditure $(\%$

of GNP) +

$\begin{array}{llllllll}\text { Education 1993-96 } & 3.0 & 2.3 & 5.2 & 2.9 & 3.4 & 3.4 & 3.1 \\ \text { Health } 1995 & 0.8 & . . & 1.3 & 1.2 & 1.4 & 0.7 & 1.2\end{array}$

Population without access to (\%)

- Health services

$\begin{array}{lllllll}45 & . . & 12 & 26 & 10 & 25 & 90\end{array}$

(1981-92)

$\begin{array}{llllllll}\text { - Safe water }(1990-97) & 52 & 33 & 22 & 5 & 43 & 19 & 29\end{array}$

\begin{tabular}{lllllll} 
- Sanitation (1990-97) & 75 & 76 & 6 & 37 & 71 & 84 \\
\hline
\end{tabular}

${ }^{1}$ Ranks of 174 countries.

..Information not available.

Source: 1. UNDP 1999, Human Development Report 1999, Oxford University Press, New York.

2. Finance Division, Economic Survey 1998-99, Government of Pakistan, Islamabad. 
Muhammad Aslam Khan 21

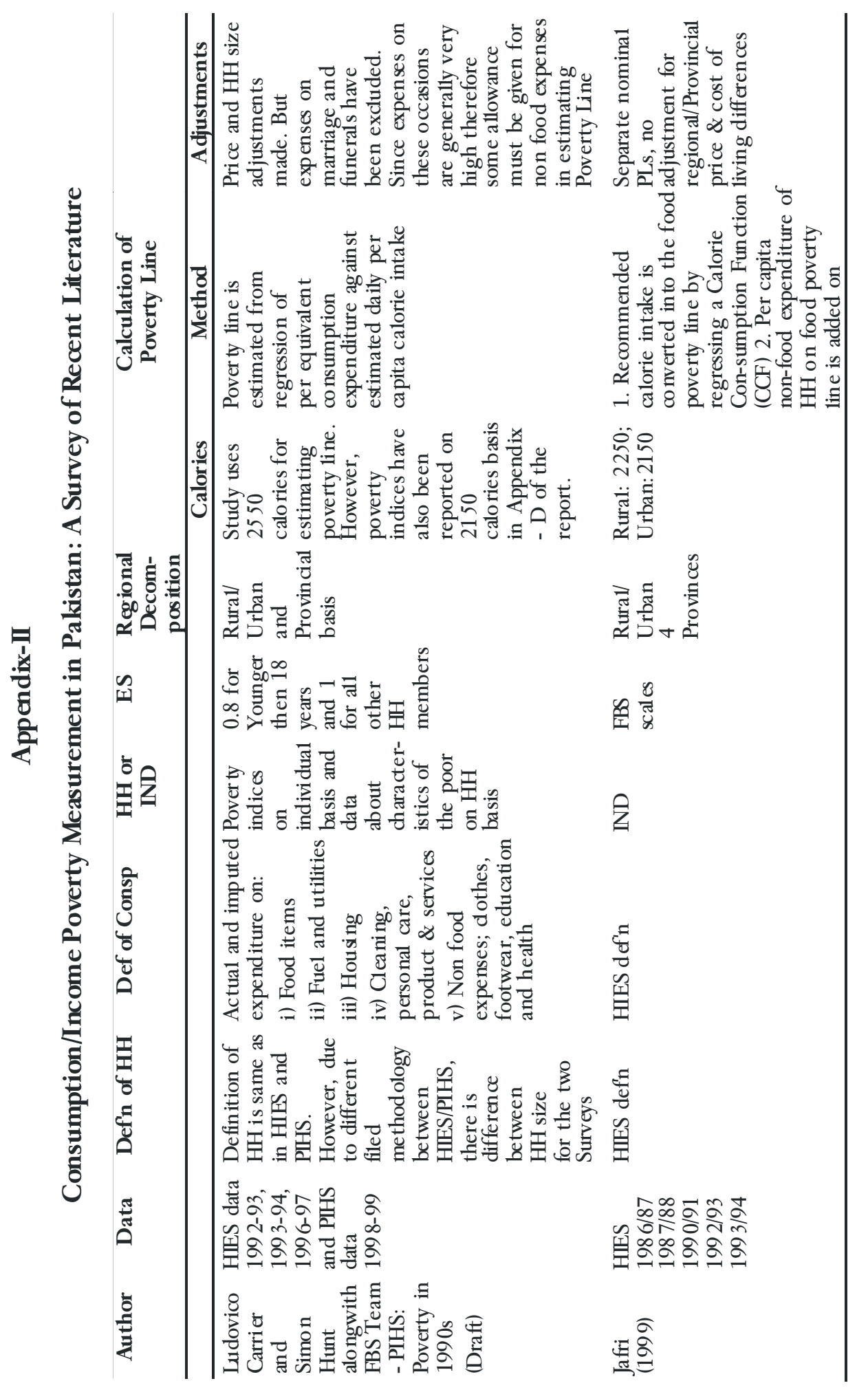




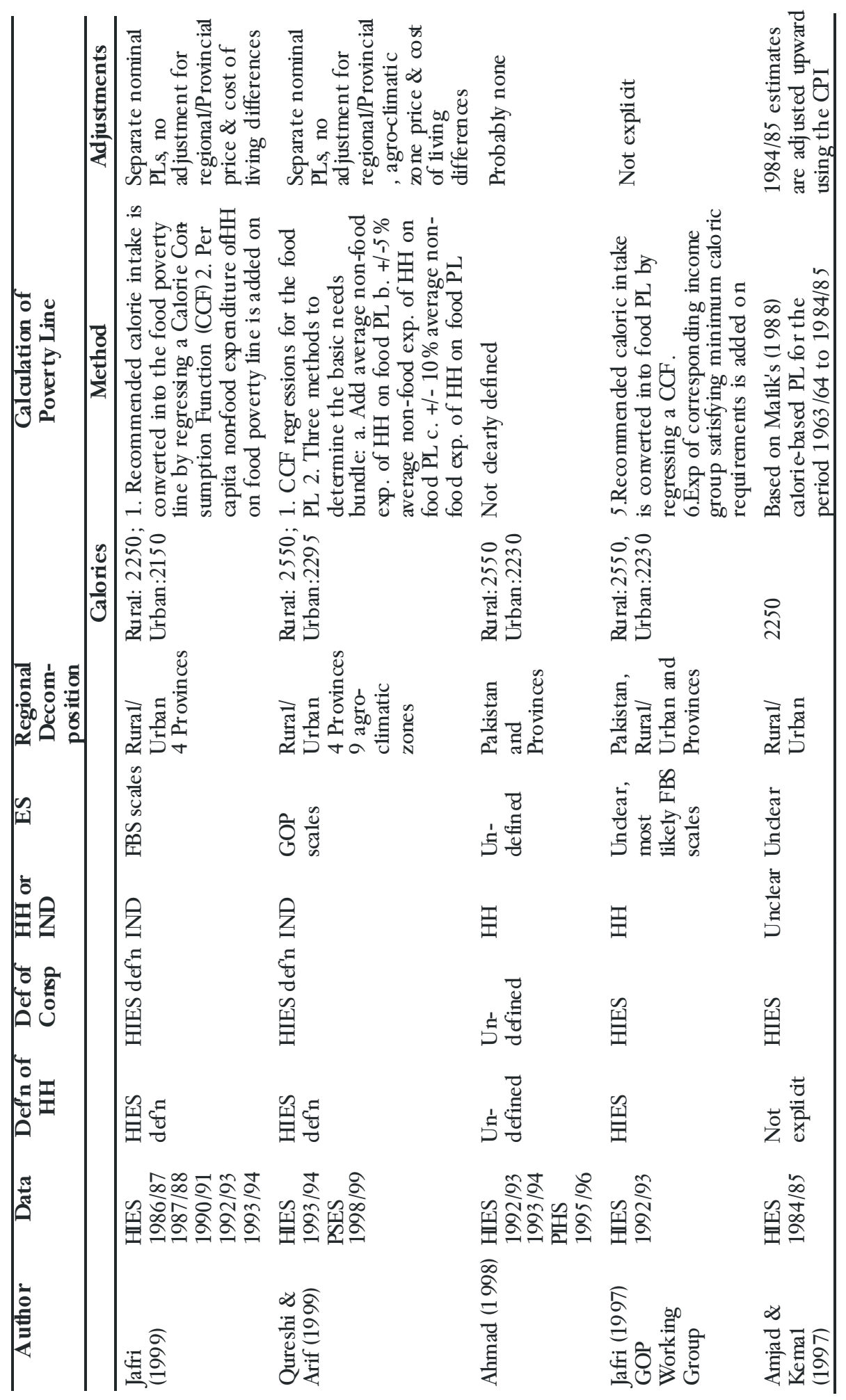




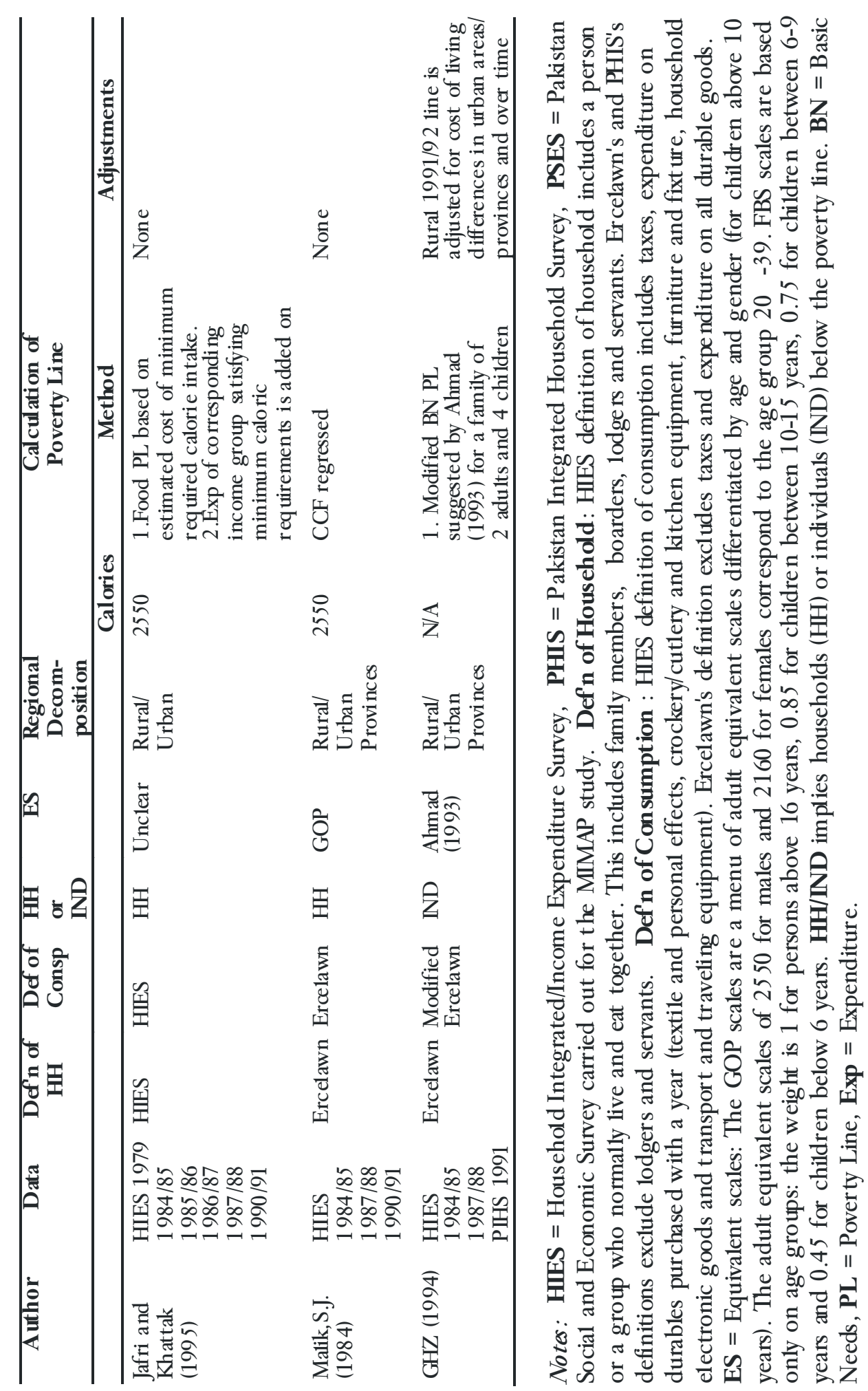


24 The Lahore Journal of Economics, Vol.6, No.2

\section{Appendix III}

Poverty Under Calorie Based Approach: Head Count Ratio

\begin{tabular}{lcccc}
\hline Years & National & \multicolumn{1}{c}{ Rural } & Urban & Poverty Line (Rs) \\
\hline $1986-87$ & 26.9 & 29.4 & 24.3 & \\
$1987-88$ & 26.4 & 29.9 & 22.7 & \\
$1990-91$ & 23.3 & 26.2 & 13.0 & \\
$1992-93$ & 22.2 & 23.9 & 17.7 & 359 \\
$1993-94$ & 23.0 & 29.7 & 13.6 & 399 \\
$1996-97$ & 21.3 & 26.0 & 12.4 & 559 \\
$1998-99$ & 23.2 & 32.0 & 19.1 & 650 \\
$1999-2000^{2}$ & 29.3 & 33.2 & 19.3 & 672 \\
$2000-2001^{2}$ & 30.0 & 34.0 & 20.3 & 684 \\
\hline
\end{tabular}

${ }^{1}$ Estimated on the basis of average 2150 -calorie intake/day basis by using HIES/PIHS data.

${ }^{2}$ Estimated on the basis of consumption plan.

Source: Federal Bureau of Statistics, 2001. Poverty in 1990s, (Draft). 


\section{Appendix-IV}

Consolidated Budgetary Position (As \% of GDP)

\begin{tabular}{ccccc}
\hline & $\begin{array}{c}\text { Government } \\
\text { Revenues }\end{array}$ & Tax Revenue & $\begin{array}{c}\text { Government } \\
\text { Expenditure }\end{array}$ & $\begin{array}{c}\text { Overall Fiscal } \\
\text { Deficit }\end{array}$ \\
\hline $1980-81$ & 17.6 & 14.0 & 22.9 & 5.3 \\
$1990-91$ & 16.9 & 12.7 & 25.7 & 8.8 \\
$1991-92$ & 19.2 & 13.7 & 26.7 & 7.5 \\
$1992-93$ & 18.1 & 13.4 & 26.2 & 8.1 \\
$1993-94$ & 17.5 & 13.4 & 23.4 & 5.9 \\
$1994-95$ & 17.3 & 13.8 & 22.9 & 5.6 \\
$1995-96$ & 17.9 & 14.4 & 24.4 & 6.5 \\
$1996-97$ & 15.8 & 13.4 & 22.3 & 6.4 \\
$1997-98$ & 16.0 & 13.2 & 23.7 & 7.7 \\
$1998-99$ & 15.9 & 13.3 & 22.0 & 6.1 \\
$1999-00$ & 16.5 & 12.8 & 22.9 & 6.4 \\
$2000-01$ & 17.4 & 13.4 & 21.3 & 5.3 \\
$2001-02$ & 18.2 & 13.8 & 21.8 & 4.9 \\
\hline
\end{tabular}


26 The Lahore Journal of Economics, Vol.6, No.2

\section{Appendix-V}

Consolidated Budgetary Position (Billion Rupees)

\begin{tabular}{lccc}
\hline & $\begin{array}{c}\text { Government } \\
\text { Revenue }\end{array}$ & $\begin{array}{c}\text { Government } \\
\text { Expenditure }\end{array}$ & $\begin{array}{c}\text { Overall Fiscal } \\
\text { Deficit }\end{array}$ \\
\hline $1980-81$ & 49.0 & 63.6 & 14.6 \\
$1990-91$ & 171.8 & 261.0 & 89.2 \\
$1991-92$ & 231.5 & 321.5 & 90.0 \\
$1992-93$ & 241.1 & 348.7 & 107.5 \\
$1993-94$ & 272.7 & 364.9 & 92.2 \\
$1994-95$ & 322.9 & 428.3 & 105.4 \\
$1995-96$ & 380.3 & 518.1 & 137.8 \\
$1996-97$ & 384.3 & 540.9 & 156.6 \\
$1997-98$ & 429.4 & 634.0 & 205.0 \\
$1998-99$ & 468.6 & 647.8 & 179.2 \\
$1999-00$ & 524.4 & 728.7 & 204.3 \\
$2000-01$ & 557.9 & 741.2 & 183.2 \\
$2001-02$ & 643.3 & 829.8 & 186.5 \\
\hline
\end{tabular}




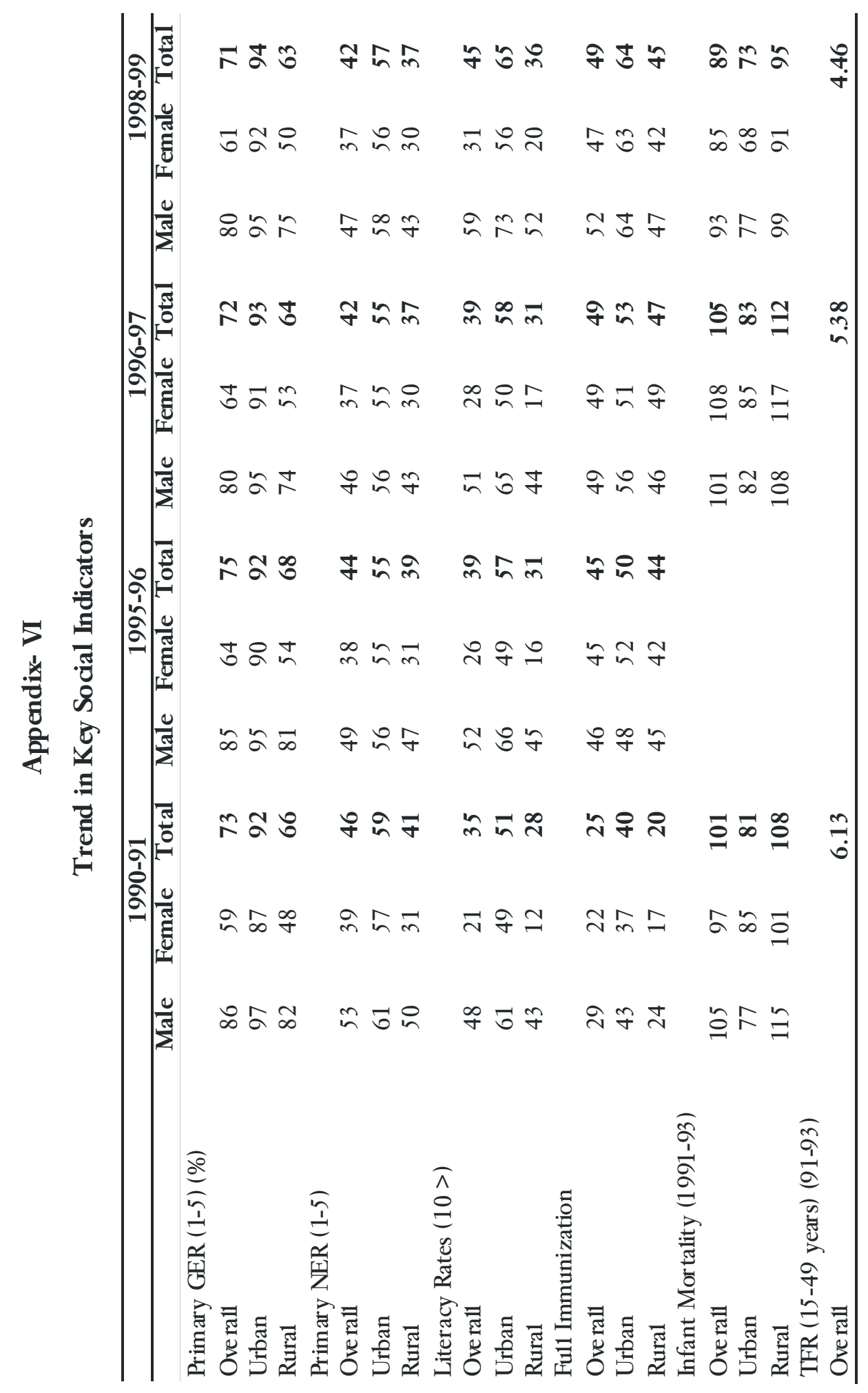


28 The Lahore Journal of Economics, Vol.6, No.2

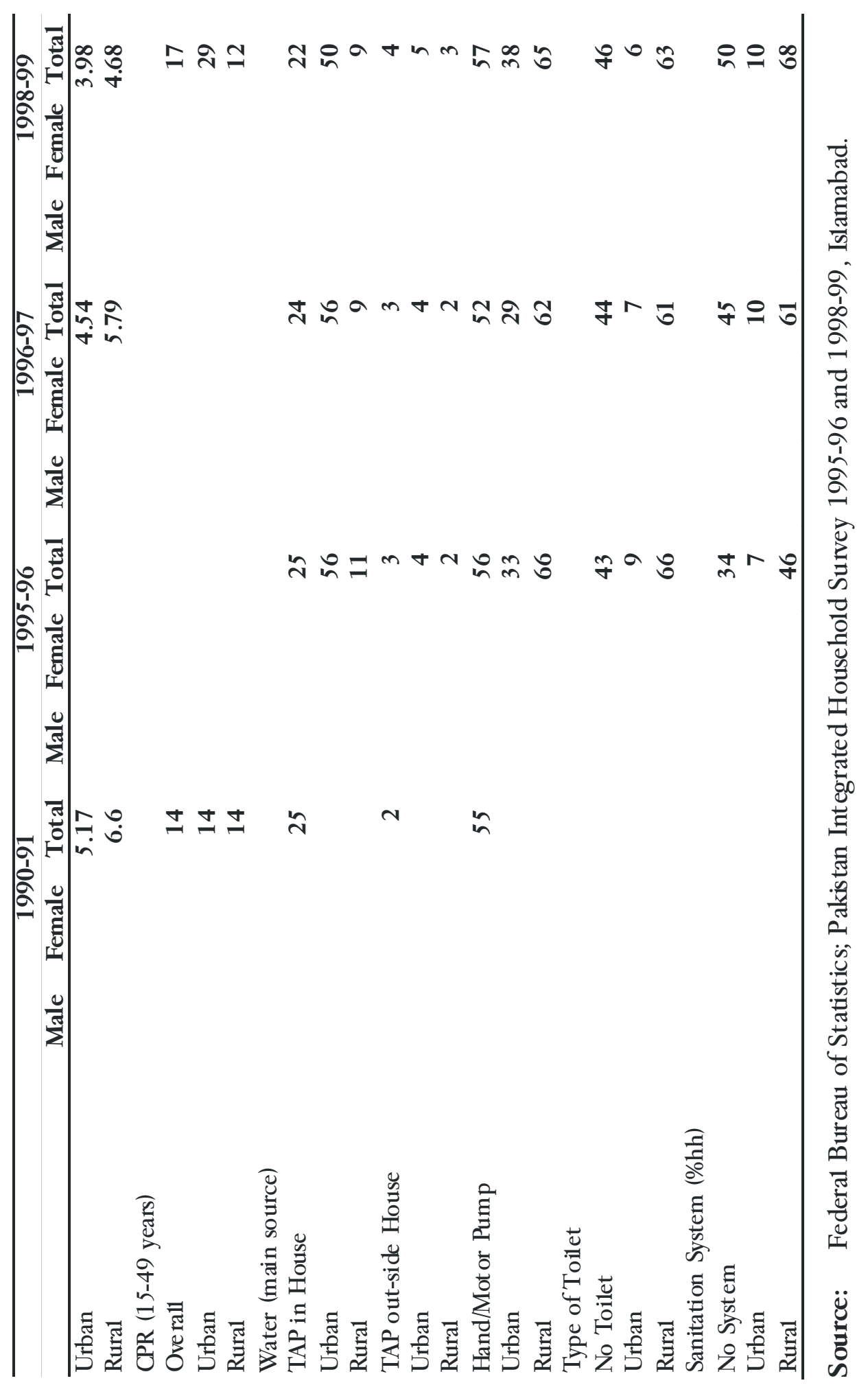




\section{References}

ActionAid Pakistan, 1999, Alliance against Poverty - Country Strategy Paper - II, 1999-2003, Islamabad: Army Press.

Amjad, R. and A. R. Kemal, 1997, Macroeconomic Policies and their Impact on Poverty Alleviation in Pakistan, ILO: Multidisciplinary Team, Mimeo.

Annan, K., 2000, "We the Peoples" The Role of the United Nations in the 21st Century, New York:United Nations.

Asian Development Bank, 1997, Social Sector Issues in Pakistan: An Overview, Manila (September).

, 1999, Supporting Growth with Equity in Pakistan: The Challenge of Human and Social Development, Manila (September).

Barr. N., 1993, The Economics of the Welfare State, London: Weidenfeld and Nicholson.

Demery, L., R. Bernier, S. Chao, K. Mehra, 1995, The Incidence of Social Spending in Ghana, 1988-92. Mimeo, February.

Department for International Development, 1998, Improving Social Sector Performance in Pakistan, Bhurban1, 8-13 February.

1999, Enhancing Capabilities for Community Participation: Revisiting Practices in Education Development, Karachi 17-19 May.

1999, Learning opportunities for all : A policy framework for education, London: DFID.

2000, Strategies for Achieving the International Development Targets: Education for All - The Challenge of Universal Primary Education, London: DFID

Federal Bureau of Statistics, 2000, Pakistan Integrated Household Survey Round 3: 1998-99, Islamabad, Government of Pakistan. (October).

1998, PIHS: Education Sector Performance in the 1990s, Islamabad, Government of Pakistan. (February).

1997, Pakistan Integrated Household Survey Round 1: $1995-$ 96, Islamabad, Government of Pakistan. (October). 
Goedhart, T., Halberstadt, V., Kapteyn, A. and van Pragg, B., 1977, The Poverty Line: Concept and Measurement, Journal of Human Resources, 4.

Gopalan, C., 1983, Measurement of Under nutrition; Biological Consideration. Economic and Political Weekly 18. 9 April.

Government of Pakistan, 2001, Economic Survey of Pakistan 2000-2001. Islamabad, Finance Division ( Economic Advisor Wing)

1999, Draft Report on Quality Indicators, Department of Education Northern Areas, Gilgit, produced with support from NAEP/DFID, July.

Government of Pakistan, 1999, Training VECs and PTAs in School Management, Department of Education Northern Areas, Gilgit, produced with support from NAEP/DFID, July.

Hossain, M., 1993, Poverty Alleviation, Report of the Task Forces (Volume-I), Bangladesh.

Human Development Centre, 1998, Human Development in South Asia 1998: The Education Challenge, Karachi: Oxford University Press.

Interagency Commission on the World Conference on Education for All., 1990, Final Report: World Conference on Education for All Meeting Basic Learning Needs, New York: WCEFA.

Irfan, M. and R. Amjad, 1984, Poverty in Rural Pakistan, in A. R. Khan and E. Lee (Ed.) Poverty in Rural Asia, Bangkok: ILO/ARTEP.

Kakwani, N., 2001, Asia and Pacific Forum on Poverty: Reforming Policies and Institutions for Poverty Reduction, Manila: 5-9 February.

Lewin, K. M., 2000a, Linking Science Education to Labour Markets: Issues and Strategies. Washington: World Bank- Education Advisory Service (Secondary Education Series). ., 2000b, Mapping Science Education Policy in Developing Countries, Washington: World Bank- Education Advisory Service, Human Development Network.

Meerman, J., 1979, Public Expenditures in Malaysia: Who Benefits and Why? New York: Oxford University Press. 
Naseem, S. M., 1973, Mass Poverty in Pakistan: Some Preliminary Findings, PDR: Winter

Planning Commission, 2001a, Three Year Poverty Reduction Programme 2001-04, Islamabad: Government of Pakistan. February 26 (Draft)

2001b, Ten Year Perspective Development Plan 2001-11 and Three Year Development Programme 2001-04, Islamabad: Government of Pakistan. September 1.

Psacharopoulos, G., 1994, Returns to Investment Education: A Global Update. World Development, 22 (9): 1325-43.

Reutlinger, S., and M. Selowsky, 1976, Malnutrition and Poverty. World Bank Occasional Papers No. 23, Washington: World Bank.

Sen, A., 1998, Poverty and Famines. India: Oxford University Press. 1987, The Standard of Living, Cambridge: Cambridge University Press.

Srinivasan, T. N., 1981, Malnutrition: Some Measurement and Policy Issues. Journal of Development Economics 8:3-19.

Sukhatme, P. V., 1977, Economics of Nutrition, Indian Journal of Agricultural Economics: 32(3):1-7.

Summers, L., 1992, Investing in All the People: Educating Women in Developing Countries. 1995. Poverty Assessment - Kenya, Report No. 13152.

UNICEF, 1998, The State of the World's Children 1999: Education, New York: UNICEF.

UNESCO, 1997, Basic Education for Empowerment of the Poor, UNESCO/PROAP, Bangkok.

World Bank, World Development Report 2000/2001: Attacking Poverty, Oxford University Press, Washington D. C.

1990, Primary Education: A World Bank Policy Paper, Washington, D. C.

, World Development Report, 1990, Oxford University Press, Washington D. C. 